\title{
Peroxynitrite Formation and Decreased Catalase Activity in Autoimmune MRL-lpr/lpr Mice
}

\author{
Teresa Keng, ${ }^{1}$ Christopher T. Privalle, ${ }^{1}$ Gary S. Gilkeson, ${ }^{2}$ and \\ J. Brice Weinberg ${ }^{3}$ \\ ${ }^{1}$ Apex Bioscience, Inc., Durham, North Carolina, U.S.A. \\ ${ }^{2}$ Medical University of South Carolina, Charleston, South Carolina, U.S.A. \\ ${ }^{3}$ Veterans Affairs and Duke University Medical Centers, Durham, \\ North Carolina, U.S.A.
}

Accepted May 23, 2000.

\begin{abstract}
Background: (MRL)-lpr/lpr mice spontaneously develop autoimmune disease characterized by arthritis and glomerulonephritis. Nitric oxide is postulated to play a role in the disease pathogenesis, as mice treated with the nitric oxide synthase inhibitor $\mathrm{N}^{\mathrm{G}}$ monomethyl-L-arginine (NMMA) show markedly reduced manifestations of the disease. The purpose of this study was to examine the role of peroxynitrite in disease development in MRL-lpr/lpr mice.

Materials and Methods: We examined kidney extracts from control and MRL-lpr/lpr mice for nitrotyrosine by immunoblot with a rabbit polyclonal anti-nitrotyrosine antibody. Catalase activity was determined spectrophotometrically or by activity staining of native polyacrylamide gels. In some experiments, we studied the ability of peroxynitrite and other agents to modify purified catalase in vitro.
\end{abstract}

Results: Kidney extracts from diseased mice had elevated levels of nitrotyrosine, and decreased levels of catalase activity and protein, relative to control mice. MRL-lpr/lpr mice treated with NMMA in vivo had decreased levels of nitrotyrosine, and demonstrated a partial restoration of both catalase activity and protein levels. Treatment of catalase in vitro with peroxynitrite or tetranitromethane at $\mathrm{pH} 8.0$ resulted in protein nitration and a decrease in catalase activity. 1,3-morpholinosydnonimine (SIN-1), a peroxynitrite generator, also decreased the activity of catalase.

Conclusions: These observations suggest that peroxynitrite formation, with an associated decrease in catalase activity and general decrease in antioxidant enzyme activity, may result in increased levels of hydrogen peroxide and other oxidants that can contribute to the pathogenesis of disease in MRL-lpr/lpr mice.

\section{Introduction}

(MRL)-lpr/lpr mice spontaneously develop aspects of autoimmune disease that include arthritis, vasculitis, and glomerulonephritis $(1,2)$. Nitric oxide (NO), a multifunctional molecule produced by many different cell types, is implicated in the pathogenesis of the disease $(3,4)$. NO is synthesized from L-arginine by the

Address correspondence and reprint requests to: J. Brice Weinberg, MD, VA \& Duke University Medical Centers, 508 Fulton Street, Durham, North Carolina 27705, U.S.A. Phone: 919-286-6833; Telefax: 919-286-6891;

E-mail: brice@acpub.duke.edu enzyme NO synthase (NOS) and is known to regulate a number of biological processes, including blood flow, neurotransmitter release, and nonspecific host defenses (5-10). Overproduction of NO is associated with inflammation and tissue injury (11-14). MRL-lpr/lpr mice excrete elevated levels of urinary nitrite/nitrate, compared with control mice, and have higher levels of blood nitrosyl-hemoglobin, both indicative of elevated systemic NO production $(4,15)$. Furthermore, detection of nitrosylated non-heme proteins in diseased kidneys suggests the formation of NO within the kidneys of diseased mice (15). In addition, macrophages from 
MRL-lpr/lpr mice express increased levels of mRNA and immunoreactive material for inducible NOS (4). Oral administration of the NOS inhibitor $\mathrm{N}^{\mathrm{G}}$-monomethyl-L-arginine (NMMA) decreases the level of nitrite/nitrate excreted by MRL-lpr/lpr mice, prevents development of glomerulonephritis, and reduces the intensity of arthritis in MRL-lpr/lpr mice (4).

In addition to overproduction of $\mathrm{NO}$, macrophages from MRL-lpr/lpr mice also produce significantly higher levels of reactive oxygen species, such as superoxide and hydrogen peroxide, in response to phorbol myristate acetate stimulation than macrophages from control mice (16). Peroxynitrite $\left(\mathrm{ONOO}^{-}\right)$is a potent oxidant that results from the reaction of superoxide with NO (17). One of the "footprints" for the presence of peroxynitrite is the nitration of tyrosine residues in the ortho position to form 3-nitrotyrosine (18). Nitrotyrosine formation is associated with many disease states, including human atherosclerosis, human acute lung injury, chronic inflammation, chronic rejection of renal allografts, and sepsis (19-23).

In this study, we examined the possibility that peroxynitrite was involved in the pathogenesis of disease in MRL-lpr/lpr mice. We found that the level of protein nitration in kidney extracts from diseased mice was elevated, compared with levels from control mice. In addition, treatment of diseased mice with NMMA decreased the extent of protein nitration.

NO and peroxynitrite can influence multiple targets important in the pathogenesis of autoimmune disease in MRL-lpr/lpr mice. These targets may include antioxidant enzymes, such as catalase and superoxide dismutase (SOD). Manganese SOD is nitrated and inactivated in chronic rejection of human renal allografts (23). In this study, we found that the activity and level of catalase protein, a heme-containing antioxidant enzyme that catalyzes the dismutation of $\mathrm{H}_{2} \mathrm{O}_{2}$ to $\mathrm{H}_{2} \mathrm{O}$ and $\mathrm{O}_{2}$, was decreased in MRL-lpr/lpr mice and was partially restored to control levels in mice treated with NMMA. This suggested that NO or a species derived from NO (e.g. peroxynitrite), may be responsible for the in vivo decrease in catalase activity. For comparison, we also examined the effects of nitrating and oxidizing agents on catalase in vitro. These agents included peroxynitrite, NO, 1,3-morpholinosydnonimine (SIN-1) and tetranitromethane (TNM). Using these agents, catalase was found to be inactivated in vitro, primarily via nitration by peroxynitrite. In toto, our results suggest that the peroxynitrite-mediated decrease in catalase activity and protein, with the increase in production of reactive oxygen species, may act together to render these mice more susceptible to oxidative damage and contribute to the pathogenesis of autoimmune disease in MRL-lpr/lpr mice.

\section{Materials and Methods}

\section{Materials}

Bovine liver catalase was obtained from Worthington Biochemical Corp., Lakewood, NJ and mouse liver catalase was from Sigma Chemical Co., St. Louis, MO. TNM was purchased from Aldrich Chemical Corporation, Milwaukee, WI. Peroxynitrite was synthesized as described by Beckman, et al. (24). Briefly, sodium nitrite and acidified hydrogen peroxide were pushed through manually driven syringes into a $\mathrm{T}$ junction. The combined solutions flowed through a short length of tubing into a second $\mathrm{T}$ junction, where the reaction was quenched with sodium hydroxide. Residual hydrogen peroxide was removed by mixing peroxynitrite with solid granular manganese dioxide, followed by filtration through a $0.2 \mu \mathrm{m}$ membrane. The concentration of peroxynitrite was determined by the absorbance at $302 \mathrm{~nm}$ using an extinction coefficient of $1.670 / \mathrm{mM} / \mathrm{cm}$.

Mice

MRL-lpr/lpr male mice were obtained from the Jackson Laboratory, Bar Harbor, ME at six weeks of age and housed as described previously (4).

\section{Kidney Extract Preparation}

Mouse kidneys were homogenized in ice-cold $50 \mathrm{mM}$ Tris, $1.0 \mathrm{mM}$ EDTA, pH 8.0, with 1.0 mM 4-(2-aminoethyl)benzenesulfonyl fluoride (AEBSF), using a glass pestle and homogenizer. The extracts were clarified by centrifugation in an Eppendorf centrifuge at 14,000 rpm for $30 \mathrm{~min}$. Each supernatant was further clarified by centrifugation for $10 \mathrm{~min}$ at $14,000 \mathrm{rpm}$. The supernatant from this second centrifugation was used in all assays.

\section{Catalase Activity Assays}

Catalase activity was determined spectrophotometrically by measuring the disappearance of 
$\mathrm{H}_{2} \mathrm{O}_{2}$ at $240 \mathrm{~nm}$ or by activity staining of $6 \%$ or $8 \%$ native polyacrylamide gels $(25,26)$. Soluble mouse kidney extracts ( $25 \mu \mathrm{g}$ of protein per lane) or purified bovine liver or mouse liver catalase were separated on $6 \%$ or $8 \%$ native polyacrylamide gels. Bands of catalase activity were visualized by soaking the gels in $50 \mathrm{mM}$ sodium phosphate, pH 7.0, 0.1 mM EDTA containing $50 \mu \mathrm{g} / \mathrm{ml}$ horseradish peroxidase for 45 min at $25^{\circ} \mathrm{C} . \mathrm{H}_{2} \mathrm{O}_{2}$ was added to a final concentration of $5.0 \mathrm{mM}$ and the gel was incubated an additional $15 \mathrm{~min}$. After a brief rinse with $\mathrm{H}_{2} \mathrm{O}$, stain development was initiated by addition of $0.5 \mathrm{mg} / \mathrm{ml}$ diaminobenzidine- $\mathrm{HCl}$ in $50 \mathrm{mM}$ sodium phosphate, $0.1 \mathrm{mM}$ EDTA, pH 7.0.

\section{Immunoblot Analysis}

Soluble mouse kidney extracts or purified bovine liver or mouse liver catalase were separated by SDS-PAGE on $8 \%$ or $14 \%$ gels and transferred to nitrocellulose membranes $(0.45$ $\mu \mathrm{m}$; Novex, Wadsworth, $\mathrm{OH})$. Unbound sites were blocked by incubation with $3 \%$ nonfat dry milk in Tris buffered saline (TBS; $20 \mathrm{mM}$ Tris, $500 \mathrm{mM} \mathrm{NaCl}, \mathrm{pH} 7.5$ ) for $2 \mathrm{hr}$ at $25^{\circ} \mathrm{C}$. Membranes were incubated overnight at $25^{\circ} \mathrm{C}$ with a rabbit polyclonal anti-nitrotyrosine antibody $(1 \mu \mathrm{g} / \mathrm{ml})$ or a sheep polyclonal antibovine catalase antibody (The Binding Site, Birmingham, England; $18 \mu \mathrm{g} / \mathrm{ml}$ ) in $1 \%$ milk/TBS. Immunoreactivity was detected by incubation with 1:2000 dilution of goat antirabbit IgG-HRP conjugate (Southern Biotechnology Associates Inc., Birmingham, $\mathrm{AL}$ or Bio-Rad, Hercules, CA) or donkey anti-sheep immunoglobulin G-horseradish peroxide (IgG-HRP) conjugate (The Binding Site). Visualization of immunoreactive proteins was carried out using Super Signal (Pierce, Rockford, IL) or Super Signal Ultra (Pierce) chemiluminescent substrates.

\section{Peroxynitrite Inactivation of Catalase}

Purified bovine liver catalase $(10 \mu \mathrm{g} / \mathrm{ml})$ or mouse liver catalase $(0.2 \mathrm{mg} / \mathrm{ml})$ was incubated in $100 \mathrm{mM}$ potassium phosphate at $\mathrm{pH}$ 7.8 with peroxynitrite at the indicated concentrations for $15 \mathrm{~min}$ at $25^{\circ} \mathrm{C}$. In control reactions, peroxynitrite was allowed to decompose in the phosphate buffer for 5-10 min before catalase was added (reverse order of addition).

\section{Sequential Addition of Peroxynitrite}

Purified bovine liver catalase $(10 \mu \mathrm{g} / \mathrm{ml})$ was incubated with $0.1 \mathrm{mM}$ peroxynitrite in $100 \mathrm{mM}$ potassium phosphate at $\mathrm{pH}$ 7.8. After $1 \mathrm{~min}$, a time sufficient for complete decomposition of peroxynitrite, a sample was removed and another aliquot of peroxynitrite was added to allow a final concentration of $0.1 \mathrm{mM}$ in the reaction mixture. This procedure was repeated until a total of five aliquots of peroxynitrite were added to the reaction.

\section{Treatment of Catalase with TNM}

Bovine liver catalase $(0.82 \mathrm{mg} / \mathrm{ml})$ was dialyzed into $100 \mathrm{mM}$ sodium phosphate, $\mathrm{pH}$ 6.0, or $100 \mathrm{mM}$ sodium phosphate, $\mathrm{pH}$ 8.0. TNM was added to a final concentration of $0.5 \mathrm{mM}$. The reactions were incubated for $2.5 \mathrm{hr}$ at $37^{\circ} \mathrm{C}$. TNM was separated from catalase using a NICK Spin column (Pharmacia Biotech, Piscataway, NJ) as per manufacturer's instructions. Aliquots were removed for determination of protein concentration and catalase activity.

\section{Inactivation of Catalase by SIN-1}

Purified bovine liver catalase $(10 \mu \mathrm{g} / \mathrm{ml})$ was incubated with $10 \mu \mathrm{M}, 100 \mu \mathrm{M}$, or $1.0 \mathrm{mM}$ SIN-1 in $100 \mathrm{mM}$ potassium phosphate at $\mathrm{pH}$ 7.8 at $25^{\circ} \mathrm{C}$. At the indicated times, an aliquot of each reaction was removed and assayed for catalase activity.

\section{The Effect of SOD on Inactivation}

of Catalase by SIN-1

Purified bovine liver catalase (Worthington) was incubated at $10 \mu \mathrm{g} / \mathrm{ml}$ in $100 \mathrm{mM}$ potassium phosphate, $\mathrm{pH} 7.8$, with $100 \mu \mathrm{M}$ SIN-1 in the absence or presence of $5 \mu \mathrm{M}$ bovine $\mathrm{Cu}, \mathrm{Zn}$ SOD (Oxis International, Portland, OR) at $25^{\circ} \mathrm{C}$. At the indicated times, an aliquot of each reaction was removed and assayed for catalase activity.

\section{Results}

Proteins in soluble extracts from kidneys of BALB/c mice and MRL-lpr/lpr mice were separated on a SDS-polyacrylamide gel and the level of protein nitration was examined using an anti-nitrotyrosine antibody. The kidney extracts from normal BALB/c mice did not contain significant levels of nitrated proteins (lanes 1 and 2, Fig. 1A). In contrast, extracts 


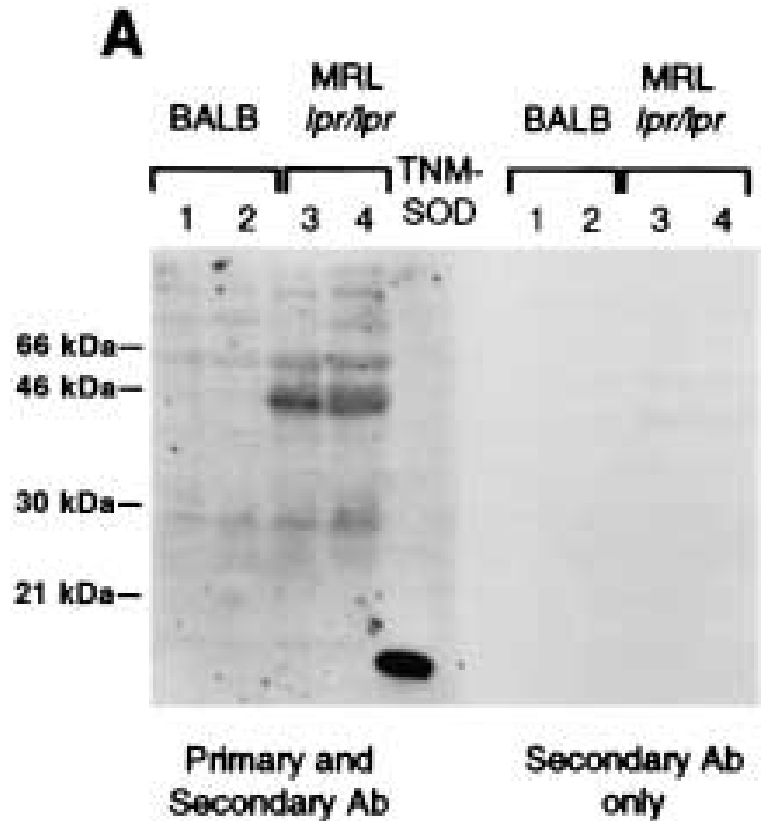

Fig. 1. Immunoblot analysis for nitrotyrosinecontaining proteins in mouse kidney extracts. Results are from one experiment that is representative of 23 analyses using tissues from 8 mice. (A) Anti-nitrotyrosine immunoblot of mouse kidney extracts. Total protein $(200 \mu \mathrm{g})$ extracted from control BALB/c (lanes 1 and 2) and MRL-lpr/lpr (lanes 3 and 4) mouse kidneys were separated on $14 \%$ SDS-PAGE and examined by immunoblot analysis with rabbit anti-nitrotyrosine antibodies and goat anti-rabbit immunoglobulin secondary antibody conjugated with horseradish peroxidase. Superoxide dismutase nitrated with tetranitromethane (TNM-SOD; $10 \mathrm{ng}$ ) served as a control. The right half contains an identical immunoblot probed only

from kidneys of MRL-lpr/lpr mice had elevated levels of proteins with nitrotyrosine (lanes 3 and 4). These proteins were seen as distinct bands, corresponding to molecular weights of approximately $27 \mathrm{kDa}$ and $52 \mathrm{kDa}$. They were specifically recognized by the anti-nitrotyrosine antibodies and were not detected in a blot incubated with secondary antibody alone (lanes 1-4, right half, Fig. 1A). Elevated levels of protein nitration seen in the diseased mouse kidneys suggested the presence of an increased level of peroxynitrite in this tissue in vivo. Peroxynitrite may be formed from the increased production of $\mathrm{NO}$ and superoxide in MRLlpr/lpr mice $(3,4,16)$. Treatment of MRL-lpr/lpr mice with the NO synthase inhibitor, NMMA, resulted in an amelioration of various aspects of the autoimmune disease (4). Treated mice excrete decreased levels of nitrite/nitrate in their urine, indicating a decreased level of NO

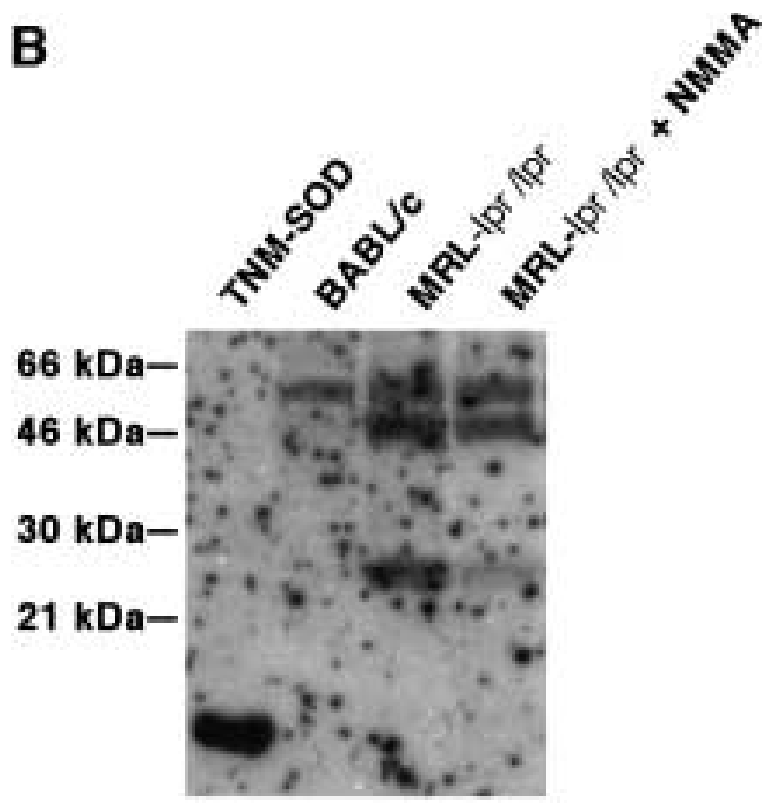

with secondary antibody. By densitometry, the band at approximately $44 \mathrm{kDa}$ is 4.9 -fold higher in samples from MRL-lpr/lpr than those from BALB mice. (B) Anti-nitrotyrosine immunoblot of mouse kidney extracts. $100 \mu \mathrm{g}$ of protein extract from BALB/c, MRL-lpr/lpr, and MRL-lpr/lpr, mice treated with $\mathrm{N}^{\mathrm{G}}$ monomethyl-L-arginine (NMMA) were separated on $14 \%$ SDS-PAGE and probed as described above. $25 \mathrm{ng}$ TNM-SOD served as a positive control. The approximate $M_{r}$ of the proteins were determined using prestained molecular weight standards. By densitometry, the band at approximately $28 \mathrm{kDa}$ is 4.2-fold higher in samples from MRL-lpr/lpr than those from BALB mice. NMMA treatment of MRLlpr/lpr mice reduces the band intensity by $59 \%$.

synthesis. In addition, the severity and extent of arthritis in the treated mice also was improved. Kidney extracts from MRL-lpr/lpr mice treated with NMMA had decreased levels of nitrated proteins, although such levels were not restored to those of the control mice (Fig. 1B).

Previous reports suggested that MRLlpr/lpr mice expressed lower levels of mRNA, corresponding to antioxidant enzymes, such as SOD and catalase, in their kidneys and livers (27). However, there has been no direct determination of the levels of these enzymatic activities in mouse kidneys to date. We examined the levels of catalase and SOD activity in kidney extracts prepared from MRL-lpr/lpr mice and compared them with the levels in kidneys from BALB/c mice. There was no difference in the level of $\mathrm{Cu}, \mathrm{Zn}$ SOD activity between the MRL-lpr/lpr kidneys and the BALB/c kidneys 

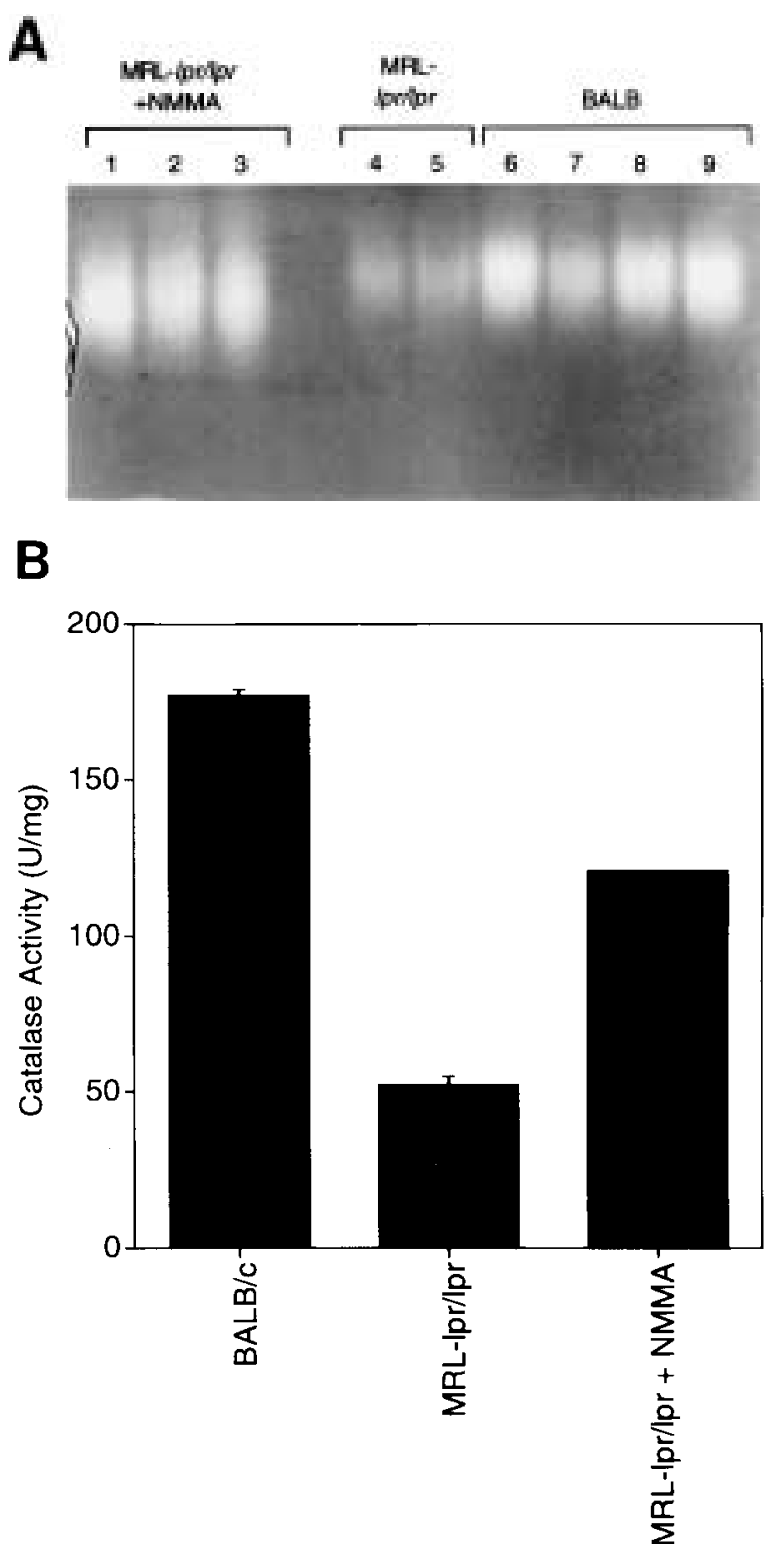

Fig. 2. Catalase activity and catalase protein levels in mouse kidney extracts. Results are from one experiment that is representative of 13 analyses using tissues from 4 mice. (A) Catalase activity stain of kidney extracts from MRL-lpr/lpr

(data not shown). In contrast, MRL-lpr/lpr mouse kidney extracts exhibited a 70-75\% decrease in catalase activity, compared with BALB/c kidney extracts (Fig. 2A and 2B). Furthermore, treatment of diseased mice with L-NMMA resulted in a partial restoration of the catalase activity.

To determine whether the decrease in catalase activity was due to a decrease in the level of catalase protein or to a decrease of activity associated with a modification of the enzyme, we examined the level of catalase protein in

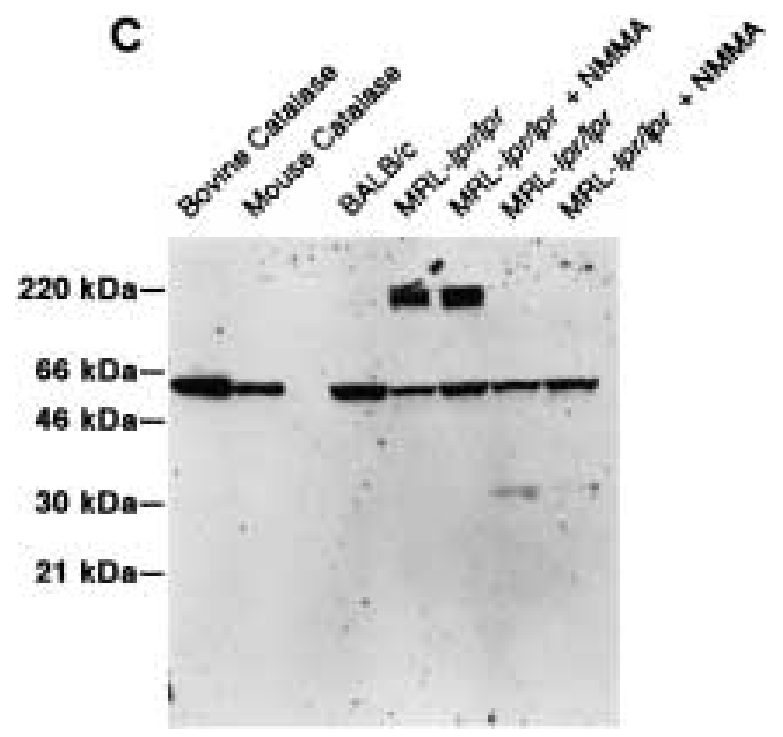

mice treated with $\mathrm{N}^{\mathrm{G}}$-monomethyl-L-arginine (NMMA) (lanes 1-3), MRL-lpr/lpr mice (lanes 4-5), and BALB/c mice (lanes 6-9). $25 \mu \mathrm{g}$ soluble protein from each extract was separated on a $6 \%$ polyacrylamide gel under native conditions and stained for catalase activity as described in "Materials and Methods." By densitometry, the catalase activity is $51 \%$ lower in samples from MRL$l p r / l p r$ than those from BALB mice. NMMA treatment of MRL-lpr/lpr mice increases catalase activity to $132 \%$ of control (BALB) levels. (B) Catalase activity of mouse kidney extracts. Catalase activity in kidney extracts of BALB/c, MRLlpr/lpr, and MRL-lpr/lpr mice treated with NMMA was determined as described. The means plus one standard deviation are displayed. (C) Anticatalase immunoblot of mouse kidney extracts. $100 \mu \mathrm{g}$ of kidney extract from BALB/c, MRL$l p r / l p r$, and MRL-lpr/lpr mice treated with NMMA were separated on $14 \%$ SDS-PAGE and probed with sheep anti-bovine catalase antibodies by immunoblot analysis. $50 \mathrm{ng}$ of bovine liver catalase and $500 \mathrm{ng}$ of mouse liver catalase served as controls. By densitometry, the catalase band is $43 \%$ lower in samples from MRL-lpr/lpr than those from BALB mice. NMMA treatment of MRL-lpr/lpr mice increased catalase back to $78 \%$ of control (BALB) levels (an increase of $45 \%$ ).

the kidney extracts, using an anti-bovine catalase antibody that cross-reacted with the mouse enzyme (Fig. 2C). The level of catalase protein was decreased in kidney extracts from the MRL-lpr/lpr mice, compared with that in BALB/c kidney extracts. Diseased mice that were treated with NMMA had levels of catalase protein intermediate between that of diseased mice and the BALB/c mice. In some (but not all) MRL-lpr/lpr mice, we noted a higher molecular mass protein recognized by the anticatalase antibody. We do not know what deter- 
mines the appearance of this. Its level was not influenced by L-NMMA treatment.

These results suggest that there is an elevated level of peroxynitrite produced in MRL-lpr/lpr mouse kidneys, as evidenced by an increase in the level of nitrated proteins. A decrease in catalase protein and activity was associated with this increase in peroxynitrite level and resulting protein nitration. To examine the effects of peroxynitrite on catalase in vitro, bovine liver catalase was treated with increasing concentrations of peroxynitrite. When added at a peroxynitrite:catalase molar ratio of $0.1: 1$ (4.1 nM peroxynitrite) to 50:1 (2.05 $\mu \mathrm{M}$ peroxynitrite), no significant decrease in catalase activity was observed. At higher concentrations of $0.1 \mathrm{mM}$ peroxynitrite, a decrease in catalase activity of $12 \%$ was observed. The catalase activity was further decreased with increasing concentrations of peroxynitrite until, at $0.5 \mathrm{mM}$ and 1.0 mM peroxynitrite, decreases of $29 \%$ and $26 \%$, respectively, were observed. Samples of catalase treated with the different concentrations of peroxynitrite were separated on $8 \%$ native gels and stained for catalase activity. Catalase samples that were treated with $0.1 \mathrm{mM}$ to $1.0 \mathrm{mM}$ peroxynitrite (concentrations associated with decreased catalase activity) had an altered migration on native gels (Fig. 3A). This suggested that peroxynitrite treatment resulted in a modification of the catalase protein. When samples of peroxynitrite-treated catalase were separated under native conditions and probed with anti-bovine catalase antibodies, all cross-reactive material co-migrated with catalase activity, indicating the absence of additional species of catalase that were inactive and that migrated with different mobilities in the native gel (Fig. 3B). No changes in catalase activity or mobility in a native gel were observed following the reverse order of addition peroxynitrite [that is, samples to which peroxynitrite was first added and allowed to decompose before catalase was added (data not shown)]. This indicated that the decrease in catalase activity was due to the effects of peroxynitrite and not due to decomposition products or contaminants.

Catalase samples treated with increasing concentrations of peroxynitrite also were separated on $8 \%$ SDS-polyacrylamide gels and subjected to immunoblot analysis using antinitrotyrosine antibodies (Fig. 3C). Catalase treated with $2.05 \mu \mathrm{M}$ peroxynitrite had a low, but detectable, level of nitrotyrosine. In contrast, catalase samples treated with $0.1 \mathrm{mM}$ to
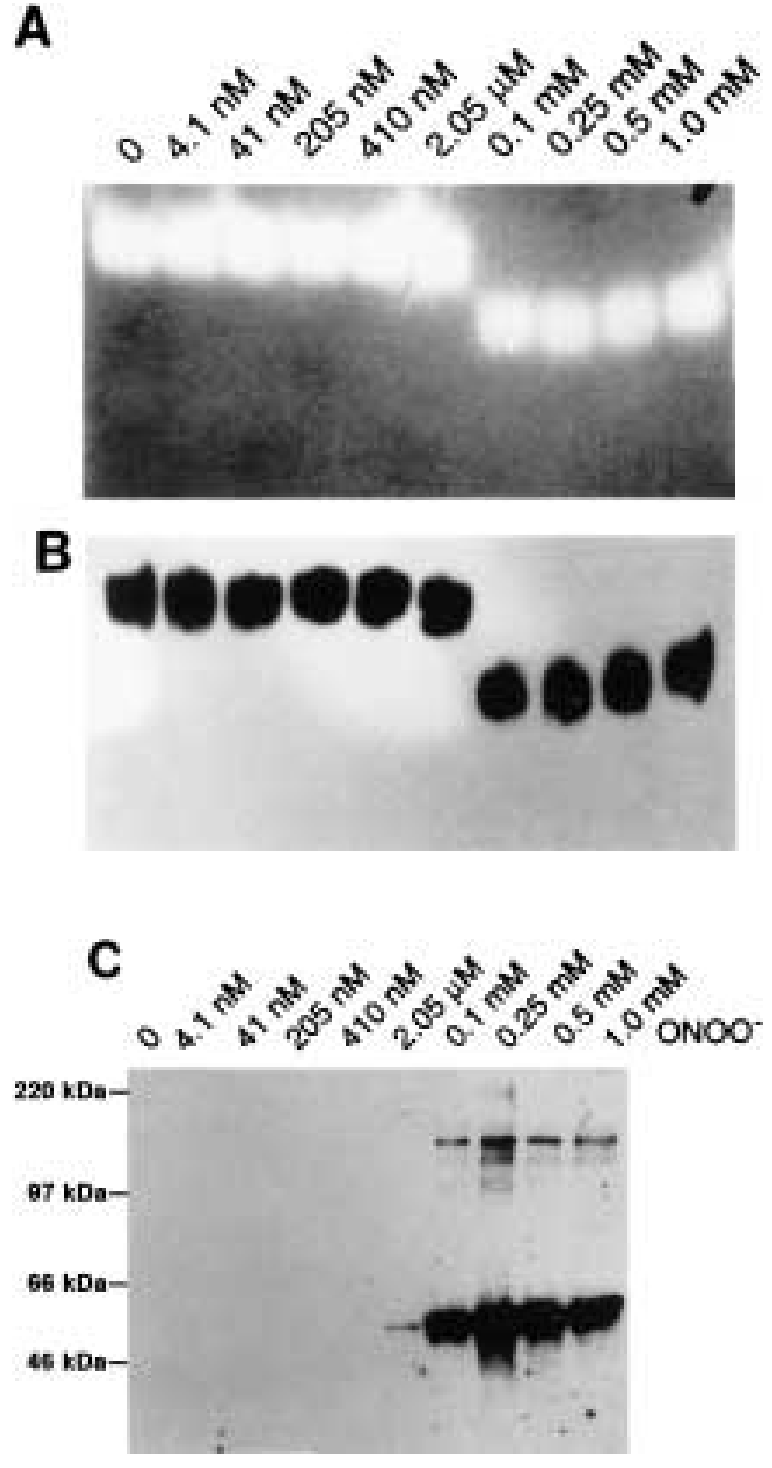

Fig. 3. Effects of increasing concentrations of peroxynitrite on bovine liver catalase. Results are from one experiment that is representative of six analyses. (A) Catalase activity stain of bovine liver catalase treated with various concentrations of peroxynitrite. Catalase (100 ng) treated with the indicated concentration of peroxynitrite was separated on an $8 \%$ polyacrylamide gel under native conditions and stained for catalase activity as described in "Materials and Methods." (B) Native immunoblot of catalase treated with peroxynitrite. 100 ng of catalase treated with the indicated concentration of peroxynitrite was separated on an $8 \%$ polyacrylamide gel under native conditions and examined in an immunoblot using polyclonal anti-catalase antibodies. (C) Anti-nitrotyrosine immunoblot of catalase incubated with peroxynitrite. $100 \mathrm{ng}$ of catalase treated with the indicated concentration of peroxynitrite was separated on $8 \%$ SDS-PAGE and the proteins subjected to immunoblot analysis with rabbit anti-nitrotyrosine antibodies. The major band of cross-reactive material comigrated with catalase monomer. 
1.0 $\mathrm{mM}$ peroxynitrite had increased nitrotyrosine formation. The majority of nitrotyrosine formation was associated with a catalase monomeric subunit with a $\mathrm{M}_{\mathrm{r}}$ of approximately 68,000 . In addition, in samples treated with 0.1 $\mathrm{mM}$ to $1.0 \mathrm{mM}$ peroxynitrite, nitrotyrosine was also associated with a protein species that had a low mobility and a $\mathrm{M}_{\mathrm{r}}$ consistent with catalase subunit dimers. This suggested that treatment of catalase with peroxynitrite at these higher concentrations resulted in the formation of catalase subunit multimers.

The effects of peroxynitrite on mouse liver catalase were very similar to those on bovine liver catalase. Incubation of mouse liver catalase with $0.1 \mathrm{mM}$ peroxynitrite resulted in a $25 \%$ decrease in enzymatic activity; whereas, incubation with $1.0 \mathrm{mM}$ peroxynitrite caused a $48 \%$ decrease in catalase activity. These decreases in enzymatic activity were accompanied by a peroxynitrite concentration-dependent increase in protein nitration and altered migration of the modified catalase on a native gel (data not shown).

Peroxynitrite is a strong oxidant, as well as nitrating agent $(28,29)$. The extent of oxidation in bovine liver catalase treated with peroxynitrite was examined using the OxyBlot oxidized protein detection system (Intergen, Boston, MA), which utilizes 2,4-dinitrophenylhydrazine to derivatize the protein carbonyls formed from oxidation to 2,4-dinitrophenylhydrazone groups (30). The derivatized protein samples were separated on SDS-polyacrylamide gels and probed with antibodies specific to the dinitrophenyl portion of the protein. Reverse-order-of-addition samples, to which peroxynitrite was first added and allowed to decompose before catalase was added, were also analyzed for comparison (Fig. 4). Addition of $2.05 \mu \mathrm{M}$ peroxynitrite to bovine liver catalase did not result in substantial levels of oxidation of the enzyme (data not shown). Protein carbonyl formation could be detected initially in samples treated with $0.1 \mathrm{mM}$ peroxynitrite. The extent of protein carbonyl formation increased when catalase was incubated with increasing concentrations of peroxynitrite. Carbonyl formation noted with the reverse order of addition samples was also substantial, an indication that the oxidation observed in the different samples was due to other oxidants present in the peroxynitrite solution and not directly to peroxynitrite itself. There was no decrease in catalase activity in the reverse-order-of-

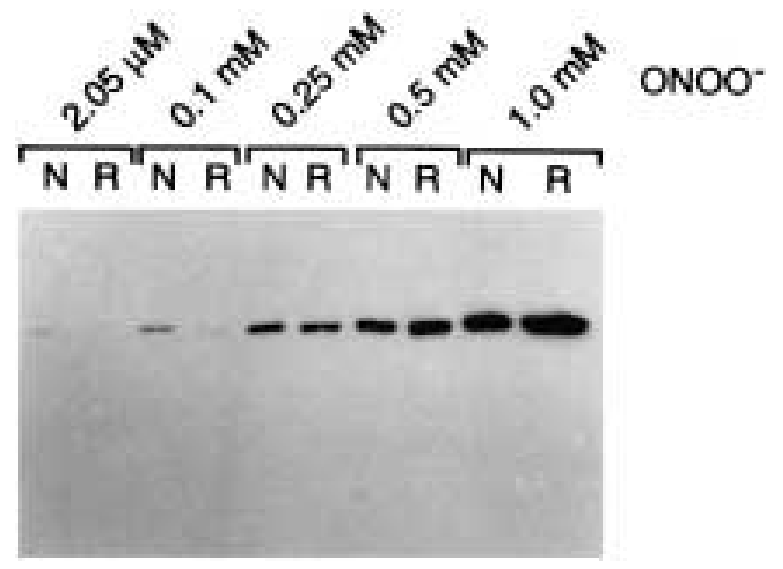

Fig. 4. OxyBlot of bovine liver catalase following treatment with increasing concentrations of peroxynitrite. Results are from one experiment that is representative of three analyses. No (DNPH)reactive carbonyl formation could be detected in untreated protein or in samples treated with low concentrations of peroxynitrite. $\mathrm{N}$ samples contained bovine liver catalase treated with the indicated concentrations of peroxynitrite. $\mathrm{R}$ samples were from reverse-order-of-addition reactions, in which the catalase was added to decomposed peroxynitrite. $50 \mathrm{ng}$ of catalase was loaded in each lane.

addition samples, suggesting that the observed level of oxidation did not contribute to the decrease in catalase activity.

Peroxynitrite is a short-lived molecule under conditions of physiological pH (31). To more closely approximate physiological conditions in which proteins may be subject to a constant source of peroxynitrite, we treated bovine liver catalase with sequential bolus additions of peroxynitrite, with each addition reaching a final concentration of $0.1 \mathrm{mM}$ in the reaction mixture. Samples were removed and analyzed after each addition. The first addition of peroxynitrite was associated with a $25 \%$ decrease in catalase activity (Fig. 5A). Further additions decreased the catalase activity only slightly. At the end of five additions of peroxynitrite, the catalase activity was decreased $45 \%$ from that of catalase without peroxynitrite treatment.

Catalase subjected to sequential peroxynitrite treatment was analyzed on native gels and stained for catalase activity. The first addition of peroxynitrite was associated with a change in migration of active catalase in the native gel (Fig. 5B). This peroxynitrite modified sample had a faster mobility than the unmodified catalase. Addition of the second and third boluses of peroxynitrite resulted in successive small 
A

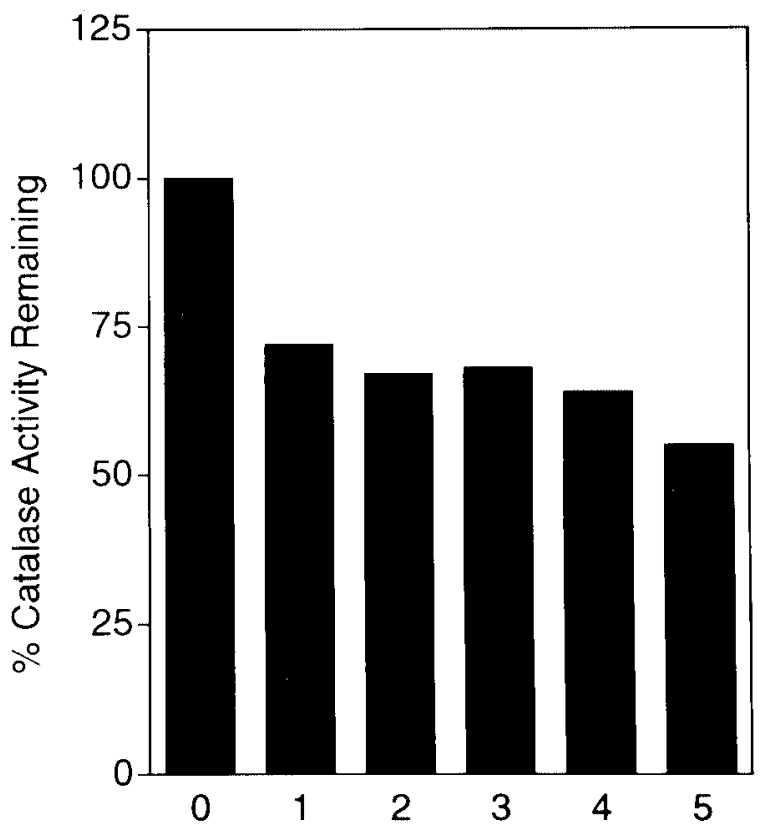

B

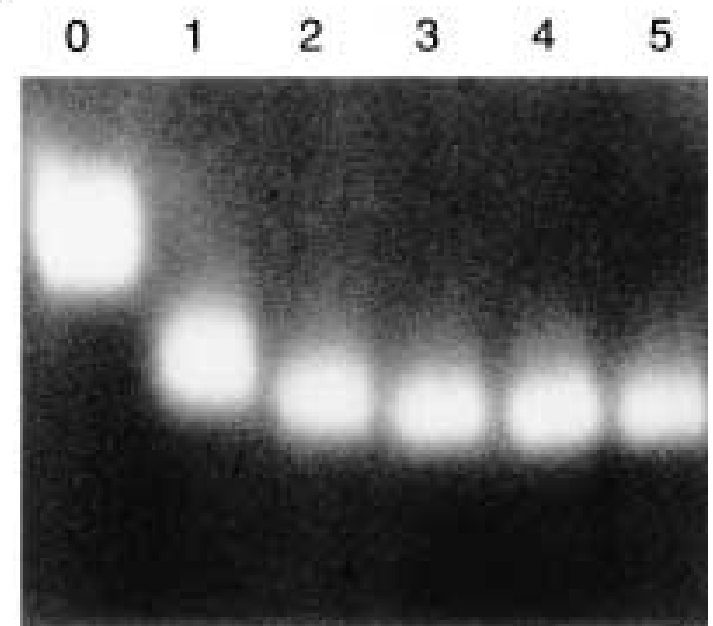

Fig. 5. Effects of sequential additions of peroxynitrite on bovine liver catalase. Results are from one experiment that is representative of five analyses. (A) Effects of sequential additions of peroxynitrite on catalase activity. Samples were removed after each addition and catalase activity determined as described in "Materials and Methods." (B) Activity stain of catalase treated with sequential additions of peroxynitrite. Samples (100 ng) were removed after each addition, separated on an $8 \%$ native gel and stained for catalase activity as described. By densitometry,

increases in mobility. Further additions of peroxynitrite did not cause further change. Immuno-blots of samples separated on a native gel probed with anti-bovine catalase antibodies indicated that all catalase cross-reactive material

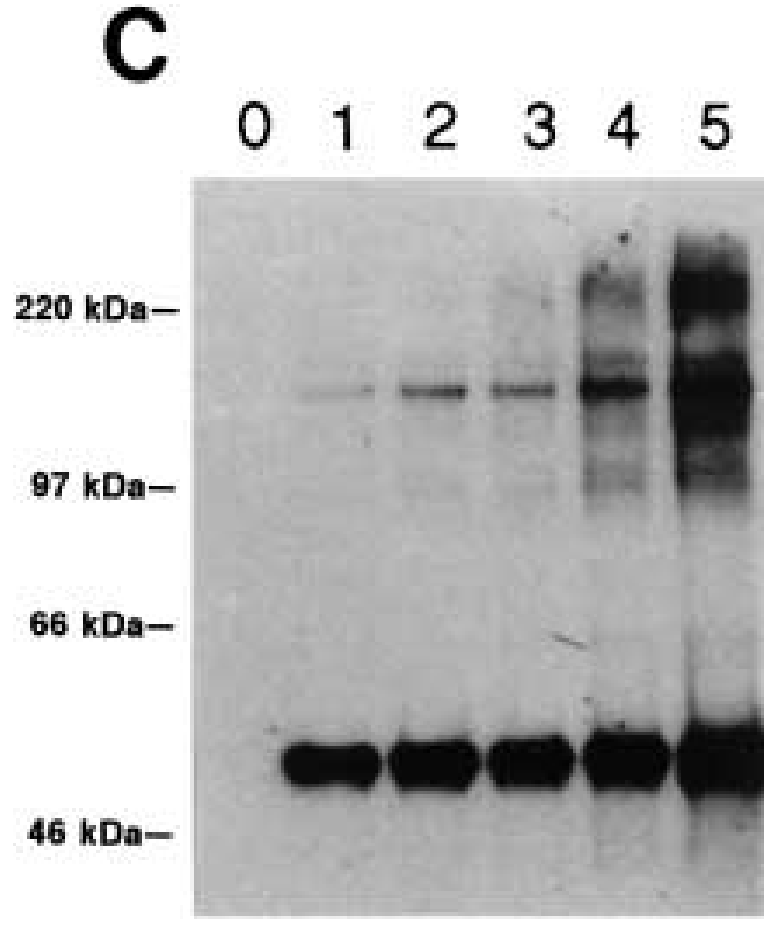

peroxynitrite treatment reduced catalase activity by $30,43,49,49$, and $57 \%$ (1, 2, 3, 4, and 5 sequential additions, respectively). (C) Anti-nitrotyrosine immunoblot of catalase treated with sequential aliquots of peroxynitrite. Samples (100 ng) were removed after each addition of peroxynitrite, separated by $8 \%$ SDS-PAGE and examined by immunoblot analysis using rabbit anti-nitrotyrosine antibodies. The major cross reactive band in each sample comigrates with catalase monomer.

co-migrated with the catalase activity. Thus, there were no additional species of catalase that were inactive and migrated to alternative positions on the native gel (data not shown).

Samples treated with sequential additions 
of peroxynitrite were also separated on SDSpolyacrylamide gels and probed with antinitrotyrosine antibodies (Fig. 5C). The first addition of peroxynitrite was associated with formation of nitrotyrosine in the catalase. Sequential additions of peroxynitrite were associated with an increased level of nitro-tyrosine formation in this protein. Additional higher molecular weight nitrotyrosine-containing species could also be detected with subsequent additions of peroxynitrite. The intensity of these species increased progressively with each additional bolus of peroxynitrite. These species represented cross-linked catalase multimers that could be detected with anti-bovine catalase antibodies (data not shown).

In addition to sequential addition of authentic peroxynitrite, another approach to expose catalase to a constant flux of peroxynitrite is to utilize SIN-1, the peroxynitrite generator (32). SIN-1 liberates NO and, in the presence of oxygen, generates superoxide (32). Thus, incubation of catalase with SIN-1, under these defined conditions, is equivalent to treatment of catalase with peroxynitrite. Incubation of bovine catalase with increasing concentrations of SIN-1 resulted in a time- and concentrationdependent decrease in catalase activity with

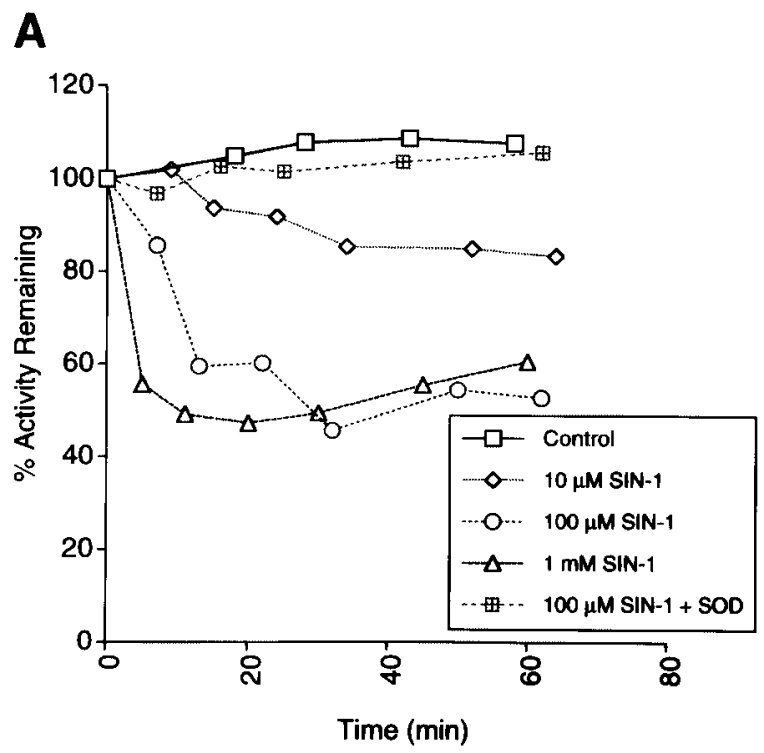

Fig. 6. Effect of SIN-1 on bovine liver catalase. Results are from one experiment that is representative of eight analyses in $\mathrm{A}$, and three analyses in B and C. (A) Effect of 6-morpholino-sydnonimine (SIN-1) on bovine liver catalase activity. Aliquots of catalase incubated with the indicated concentrations of SIN-1 were removed at different times and assayed for catalase activity. In addition, catalase the rate of decrease correlating with increasing concentrations of SIN-1 (Fig. 6A). With $10 \mu \mathrm{M}$ SIN-1, the catalase was inactivated very slowly, such that, after 60 min only $20 \%$ of the activity was lost. Incubation with $100 \mu \mathrm{M}$ and $1.0 \mathrm{mM}$ SIN-1 resulted in a progressive increase in loss of catalase activity. With the two higher concentrations of SIN-1, there was a $50 \%$ loss of catalase activity after $60 \mathrm{~min}$, similar to the decrease observed with authentic peroxynitrite.

To ensure that the peroxynitrite generated by SIN-1 (and not simply NO) was responsible for the observed inactivation, samples were incubated with SIN-1 in the presence of SOD, which would convert any released superoxide to hydrogen peroxide and prevent the formation of peroxynitrite. Catalase treated with SIN-1 in the presence of SOD retained all catalase activity, indicating that NO itself did not inactivate catalase under these conditions (Fig. 6A). In addition, up to $100 \mu \mathrm{M}$ NO added

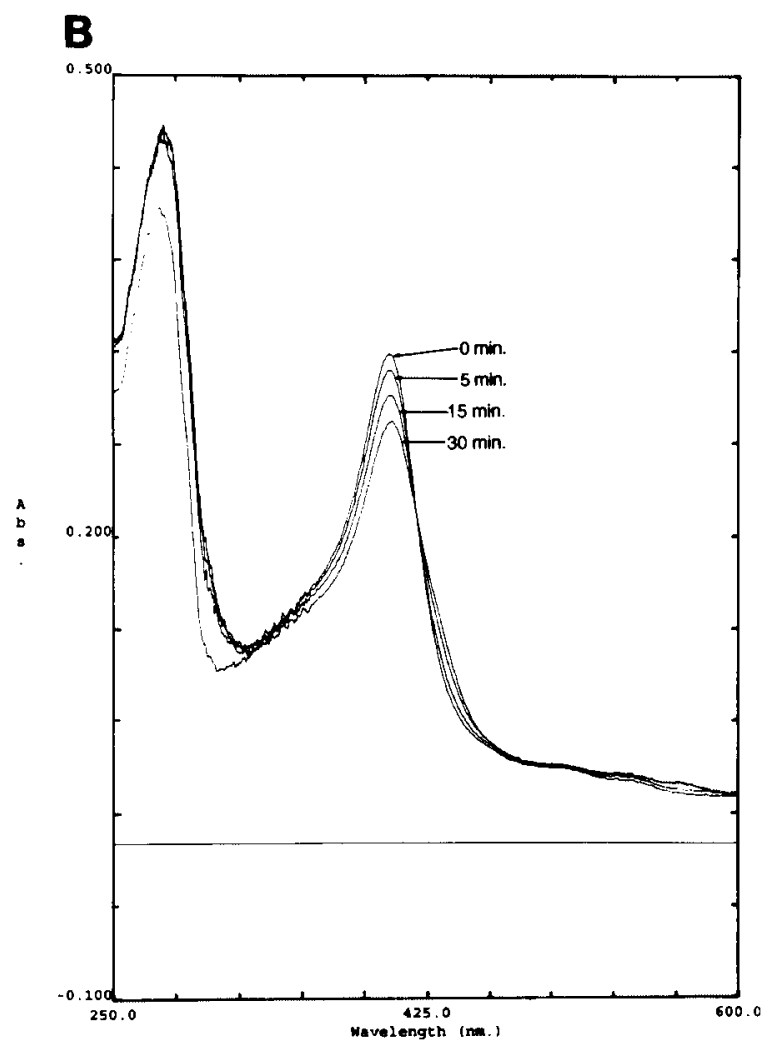

was incubated with $100 \mu \mathrm{M}$ SIN-1 and $5 \mu \mathrm{M}$ superoxide dismutase (SOD). Samples were removed at various times and assayed for catalase activity. (B) Effect of SIN-1 on the spectrum of bovine liver catalase. Catalase was incubated with $100 \mu \mathrm{M}$ SIN-1 and the spectrum was determined at the indicated times after the initiation of the experiment. 
A

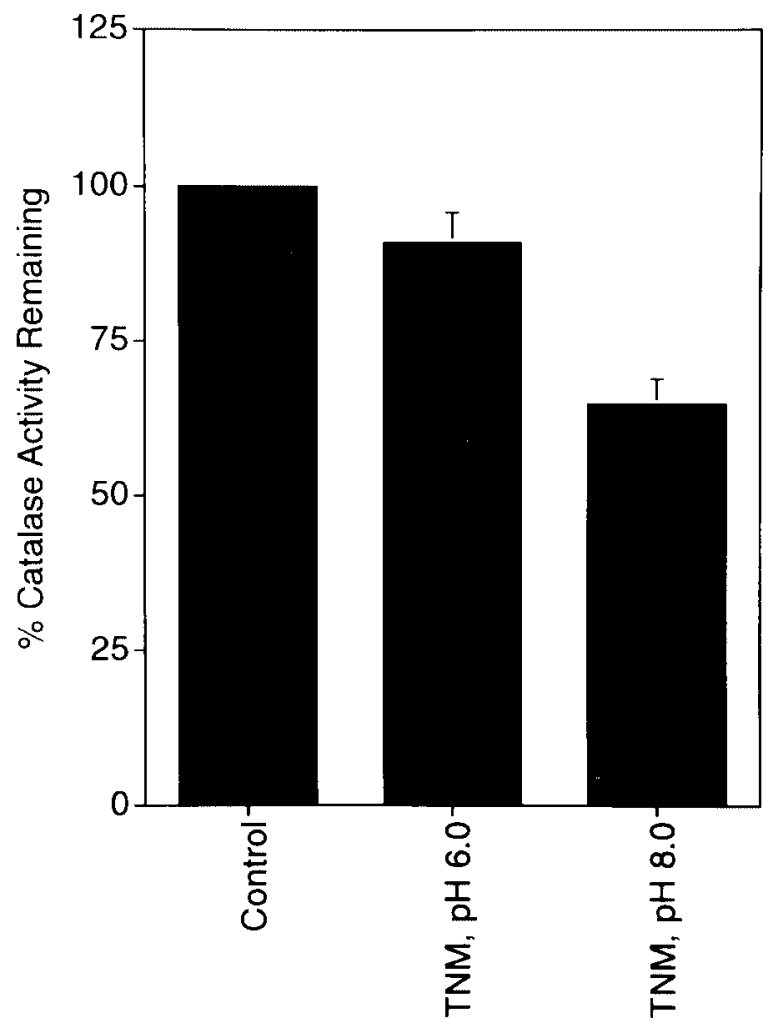

Fig. 7. Effect of TNM treatment on bovine liver catalase. Results are from one experiment that is representative of three analyses. (A) Effect of tetranitromethane (TNM) treatment at $\mathrm{pH} 6.0$ and pH 8.0 on catalase activity. Catalase was treated with $0.5 \mathrm{mM}$ TNM at pH 6.0 and 8.0 as described in "Materials and Methods." The means plus one standard deviation are displayed. (B) Anti-nitrotyrosine immunoblot analysis of catalase treated with TNM. Bovine liver catalase $(5 \mathrm{ng})$ treated with TNM at pH 6.0 and pH 8.0 was separated by $14 \%$ SDS-PAGE and examined by immunoblot analysis using rabbit anti-nitrotyrosine antibodies.

directly to the catalase did not have an effect on catalase activity (data not shown).

Addition of SIN-1 affected the spectrum of bovine liver catalase in both the visible and ultraviolet (UV) regions (Fig. 6B). With increased time of exposure to SIN-1, the peak absorbance at $415 \mathrm{~nm}$ decreased, indicating that there was a perturbation of the region surrounding the heme pocket. The precise nature of this perturbation has not yet been investigated.

Treatment of catalase with peroxynitrite resulted in both oxidation and nitration of the protein. To determine which of these processes was responsible for the loss of catalase activity, bovine liver catalase was treated with TNM at various pHs. At $\mathrm{pH}$ 6.0, TNM primarily oxi-
B

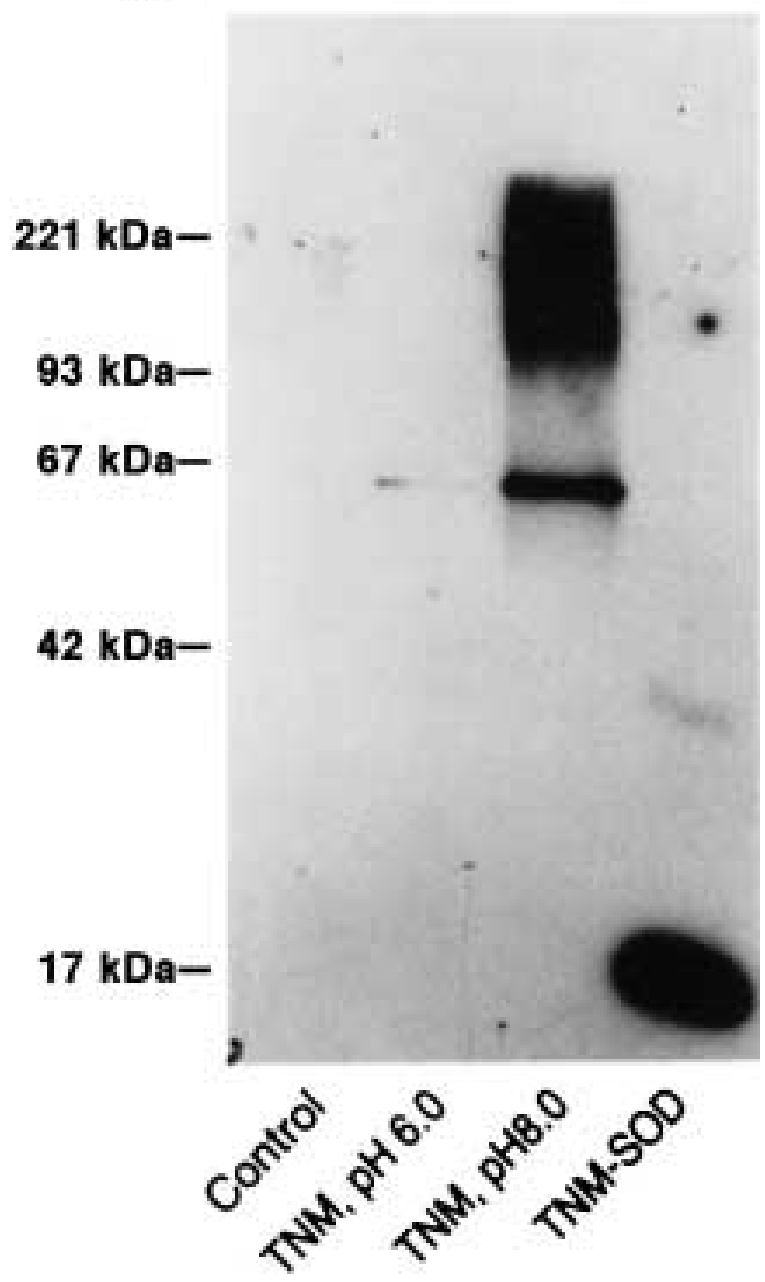

dizes the enzyme; whereas, at $\mathrm{pH} 8.0$, nitration is the primary modification $(33,34)$. Following TNM treatment at $\mathrm{pH} 6.0$, a $10 \%$ decrease in enzymatic activity was observed and treatment with the same concentration of TNM at pH 8.0 resulted in a $35 \%$ decrease in catalase activity (Fig. 7A). Immunoblot analysis with antinitrotyrosine antibodies revealed that the sample treated with TNM at pH 6.0 exhibited a low level of nitrotyrosine formation; whereas, the sample that was treated with TNM at $\mathrm{pH} 8.0$ showed a high level of nitrotyrosine formation (Fig. 7B). These observations with TNM suggested that protein nitration was associated with a greater decrease in catalase activity than sulfhydryl oxidation.

\section{Discussion}

In MRL-lpr/lpr mice, increased production of NO is associated with manifestation of various aspects of autoimmune disease, including arthritis 
and glomerulonephritis $(3,4)$. The macrophages of the diseased mice also produce elevated levels of superoxide and hydrogen peroxide (16). In the current study, we have shown that diseased kidneys contain an elevated level of protein nitration. Although it recently was demonstrated that protein nitration can arise from species other than peroxynitrite (35), 3-nitrotyrosine staining was immunochemically detected in several diseases encompassing every major organ system and was proposed to be a footprint of peroxynitrite action (36). Enhanced protein nitration was consistent with overproduction of peroxynitrite from the increased levels of NO and superoxide found in these mice, although several nitration pathways could exist simultaneously (36). Treatment of MRL-lpr/lpr mice with the NOS inhibitor NMMA reduces the extent of nitration. In addition to increased protein nitration, catalase activity in the diseased kidney extracts is also diminished. This diminution is also NO-dependent, since mice treated with NMMA have a partial restoration of catalase activity. The decrease in catalase activity is paralleled by a decrease in the level of catalase protein; this decrease is partially prevented in MRL-lpr/lpr mice treated with NMMA. These results suggest that nitration of catalase in the kidneys of MRL-lpr/lpr mice may result in enhanced degradation of the catalase protein. Venkatraman, et al. (27) examined the level of catalase mRNA in MRL-lpr/lpr kidneys and found that there was no difference between the levels in diseased kidneys and control kidneys. These data are consistent with a model in which the catalase protein is subject to degradation following nitration. Catalase appears to be important for the protection of rats against oxidant-mediated kidney damage. Puromycin aminonucleoside nephrosis in rats is associated with a decrease in catalase activity (37). Moreover, a recent report documented that in vivo inhibition of catalase activity with 3-amino1,2,4-triazole exacerbates the renal damage and proteinuria in these rats, suggesting a role for hydrogen peroxide in pathogenesis of kidney disease (37).

The amino acid sequence of mouse catalase is greater than $95 \%$ identical to that of bovine liver catalase $(38,39)$. In vitro treatment of both catalases with peroxynitrite decreases their activities. This reduction is accompanied by both nitration and oxidation of the protein. However, if the peroxynitrite first was allowed to decompose before catalase was added, no decrease in catalase activity or nitration was ob- served. However, the protein was still oxidized, suggesting that oxidation, per se, did not have any effect on enzyme activity. Further support for this contention was provided by examination of the effects of TNM treatment on catalase activity. Treatment with TNM at $\mathrm{pH}$ 6.0, resulting in oxidation of the sulfhydryl groups of the enzyme, was not associated with significant loss of catalase activity. In contrast, treatment with TNM at pH 8.0 primarily resulted in protein nitration and was associated with in a decrease in enzymatic activity. Moreover, catalase activity was decreased in the presence of the peroxynitrite generator SIN-1 in a concentration-dependent manner. SIN-1 was found to have no effect on catalase activity when SOD (which scavenges superoxide radical and, therefore, prevents the formation of peroxynitrite) was present.

The three-dimensional structure of bovine liver catalase reveals the active site to consist of a heme prosthetic group with Tyr357 as the proximal heme ligand (40). Electron paramagnetic resonance (EPR) spectroscopy suggests the involvement of a tyrosyl radical in the catalytic activity of the enzyme (41). Nitration of this tyrosine residue could lead to inactivation of the enzyme. Bovine liver catalase treated with SIN-1 has an altered spectrum, compared with untreated enzyme. This suggests that there is a perturbation of the heme pocket, an observation that is consistent with predictions from the structure of the enzyme. In vitro observations, including enhanced electrophoretic mobility on native gels, indicative of a decrease in the pKa, are consistent with tyrosine nitration. In addition, the decrease in activity coupled with the failure to observe a second, inactive species, suggests that nitration leads to a single species of protein that is only partially active. The precise mechanism of inactivation awaits further investigation. The reaction of peroxynitrite with proteins not only results in the nitration of tyrosines, but also in the nitration and oxidation of other amino acids, such as tryptophan, cysteine, and methionine, as well as in the formation of dityrosine $(28,29,42-44)$. We have not yet investigated the modification of these other amino acids that may further affect the activity of catalase.

Bovine liver catalase, although a hemoprotein, was not inactivated by authentic NO under conditions of this study. This finding appears to be at odds with a number of published observations that describe the inactivation of catalase by NO (45-47). Upon closer examina- 
tion, the difference may be attributed to the precise conditions of the various experiments. In the study of Kim, et al. (46) the decrease in catalase activity was associated with an increase in NO production in hepatocytes. Under such conditions, there also could be increased production of peroxynitrite that could be responsible for inactivation of the catalase. In the work of Brown (45), the decrease in catalase activity caused by NO was observed in the presence of hydrogen peroxide. Under these conditions, catalase is converted to compound I, and compound I is inactivated by NO. This conclusion is supported by the observations of Mohazzab-H, et al. (47), who also suggests that compound I formation is required for inactivation by NO.

Several proteins to date have been shown to be nitrated and inactivated by peroxynitrite in vitro. These include antioxidant enzymes, such as manganese SOD (MnSOD) and glutathione peroxidase (an enzyme also inactivated by NO) (48-52). In addition, peroxynitrite has been implicated in the nitration of a number of different proteins under pathophysiological conditions. This includes MnSOD, which is nitrated and inactivated in human rejecting renal allograft (23). For this enzyme, Tyr34 at the active site of MnSOD is the most susceptible to nitration by peroxynitrite (53).

In summary, MRL-lpr/lpr mice produce elevated levels of oxidants, including hydrogen peroxide, NO, superoxide and peroxynitrite. Increased levels of these oxidants, coupled with diminished levels of antioxidants, result in exaggerated oxidant stress. This likely contributes to the pathogenesis of this autoimmune disease.

\section{Acknowledgements}

The work was supported in part by the Veterans Affairs Research Service, NIH grants AI41764 and AR-39162, and the James Swiger Hematology Research Fund.

\section{References}

1. Andrews BS, Eisenberg RA, Theofilopoulos AN, et al. (1978) Spontaneous murine lupuslike syndromes. Clinical and immunological manifestations in several strains. J. Exp. Med. 148: 1198-1215.

2. Cohen PL, Eisenberg RA. (1991) Lpr and gld: single gene models of systemic autoimmunity and lymphoproliferative disease. Ann. Rev. Immunol. 9: 243-269.

3. Huang FP, Feng GJ, Lindop G, Stott DI, Liew FY. (1996) The role of interleukin 12 and nitric oxide in the development of spontaneous autoimmune disease in MRL:MP-lpr:lpr mice. $J$. Exp. Med. 183: 1447-1459.

4. Weinberg JB, Granger DL, Pisetsky DS, et al. (1994) The role of nitric oxide in the pathogenesis of spontaneous murine autoimmune disease: increased nitric oxide production and nitric oxide synthase expression in MRL-lpr/lpr mice, and reduction of spontaneous glomerulonephritis and arthritis by orally administered $\mathrm{N}^{\mathrm{G}}$ monomethyl-L-arginine. J. Exp. Med. 179: 651660.

5. Bredt DS, Snyder SH. (1994) Nitric oxide: a physiologic messenger molecule. Ann. Rev. Biochem. 63: 175-195.

6. Feldman PL, Griffity OW, Stuehr DJ. (1993) Nitric oxide chemistry. Chem. Eng. News 63: 26-38.

7. Green SJ, Scheller LF, Marletta MA, et al. (1994) Nitric oxide: cytokine-regulation of nitric oxide in host resistance to intracellular pathogens. Immunol. Lett. 43: 87-94.

8. Macmicking J, Xie QW, Nathan C. (1997) Nitric oxide and macrophage function [Review]. Ann. Rev. Immunol. 15: 323-350.

9. Moncada S, Palmer RMJ, Higgs EA. (1991) Nitric oxide: physiology, pathophysiology and pharmacology. Pharmacol. Rev. 43: 109-142.

10. Schuman EM, Madison DV. (1994) Nitric oxide and synaptic function. Ann. Rev. Med. 17: 153-183.

11. Clancy RM, Abramson SB. (1995) Nitric oxide-a novel mediator of inflammation [Review]. Proc. Soc. Exp. Biol. Med. 210: 93-101.

12. Cobb JP, Danner RL. (1996) Nitric oxide and septic shock. JAMA 275: 1192-1196.

13. McInnes IB, Leung BP, Field M, et al. (1996) Production of nitric oxide in the synovial membrane of rheumatoid and osteoarthritis patients. J. Exp. Med. 184: 1519-1524.

14. Royall JA, Kooy NW, Beckman JS. (1995) Nitric oxide-related oxidants in acute lung injury. New Horizons 3: 113-122.

15. Weinberg JB, Gilkeson GS, Mason RP, Chamulitrat W. (1998) Nitrosylation of blood hemoglobin and renal nonheme proteins in autoimmune MRL-lpr/lpr mice. Free Radic. Biol. Med. 24: 191196.

16. Dang-Vu AP, Pisetsky DS, Weinberg JB. (1987) Functional alterations of macrophages in autoimmune MRL-lpr/lpr mice. J. Immunol. 138: 1757-1761.

17. Huie RE, Padmaja S. (1993) The reaction of NO with superoxide. Free Rad. Res. Comm. 18: 19501959.

18. Beckman JS, Ischiropoulos $\mathrm{H}, \mathrm{Zhu} \mathrm{L}$, et al. (1992) Kinetics of superoxide dismutase- and 
iron-catalyzed nitration of phenolics by peroxynitrite. Arch. Biochem. Biophys. 298: 438-445.

19. Beckman JS, Ye YZ, Anderson PG, et al. (1994) Extensive nitration of protein tyrosines in human atherosclerosis detected by immunohistochemistry. Biol. Chem. Hoppe-Seyler 375: 81-88.

20. Kaur H, Halliwell B. (1994) Evidence for nitric oxide-mediated oxidative damage in chronic inflammation-nitrotyrosine in serum and synovial fluid from rheumatoid patients. FEBS Lett. 350: 9-12.

21. Kooy NW, Lewis SJ, Royall JA, et al. (1997) Extensive tyrosine nitration in human myocardial inflammation-evidence for the presence of peroxynitrite. Crit. Care Med. 25: 812-819.

22. Kooy NW, Royall JA, Ye YZ, Kelly DR, Beckman JS. (1995) Evidence for in vivo peroxynitrite production in human acute lung injury. Am. J. Respir. Crit. Care Med. 151: 1250-1254.

23. MacMillan-Crow LA, Crow JP, Kerby JD, Beckman JS, Thompson JA. (1996) Nitration and inactivation of manganese superoxide dismutase in chronic rejection of human renal allografts. Proc. Natl. Acad. Sci. U.S.A. 93: 11853-11858.

24. Beckman JS, Chen J, Ischiropoulos H, Crow JP. (1994) Oxidative chemistry of peroxynitrite. Methods Enzymol. 233: 229-240.

25. Beers RF, Sizer IW. (1952) A spectrophotometric method for measuring the breakdown of hydrogen peroxide by catalase. J. Biol. Chem. 195: 133140.

26. Clare DA, Duong MN, Darr D, Archibald F, Fridovich I. (1984) Effects of molecular oxygen on detection of superoxide radical with nitroblue tetrazolium and on activity stains for catalase. Anal. Biochem. 140: 532-537.

27. Venkatraman JT, Chandrasekar B, Kim JD, Fernandes G. (1994) Genotype effects on the antioxidant enzymes activity and mRNA expression in liver and kidney tissues of autoimmuneprone MRL/MpJ-lpr/lpr mice. Biochim. Biophys. Acta 1213: 167-175.

28. Ischiropoulos H, Al-Mehdi AB. (1995) Peroxynitrite-mediated oxidative modifications. FEBS Lett. 364: 279-282.

29. Radi R, Beckman JS, Bush KM, Freeman BA. (1991) Peroxynitrite oxidation of sulfhydryls. The cytotoxic potential of superoxide and nitric oxide. J. Biol. Chem. 266: 4244-4250.

30. Robinson CE, Keshavarzian A, Pasco DS, et al. (1999) Determination of protein carbonyl groups by immunoblotting. Anal. Biochem. 266: 48-57.

31. Beckman JS, Beckman TW, Chen J, Marshall PA, Freeman BA. (1990) Apparent hydroxyl radical production by peroxynitrite: implications for endothelial injury from nitric oxide and superoxide. Proc. Natl. Acad. Sci. U.S.A. 87: 1620-1624.

32. Feelisch M, Ostrowski J, Noack E. (1989) On the mechanism of NO release from sydnonimines. J. Cardiovasc. Pharmacol. 14 (Suppl 11): S13.
33. Sokolovsky M, Harell D, Riordan JF. (1969) Reaction of tetranitromethane with sulfhydryl groups in proteins. Biochem. 8: 4740-4745.

34. Sokolovsky M, Riordan JF, Vallee BL. (1966) Tetranitromethane. A reagent for the nitration of tyrosyl residues in proteins. Biochem. 5: 3582-3589.

35. Eiserich JP, Hristova M, Cross CE, et al. (1998) Formation of nitric oxide derived inflammatory oxidants by myeloperoxidase in neutrophils. Nature 391: 393-397.

36. Ischiropoulos H. (1998) Biological tyrosine nitration - a pathophysiological function of nitric oxide and reactive oxygen species [Review]. Arch. Biochem. Biophys. 356: 1-11.

37. Pedraza-Chaverri J, Granados-Silvestre MDLA, Medina-Campos ON, Hernández-Pando R. (1999) Effect of the in vivo catalase inhibition on aminonucleosides nephrosis. Free Radic. Biol. Med. 27: 245-253.

38. Shaffer JB, Preston KE. (1990) Molecular analysis of an acatalasemic mouse mutant. Biochem. Biophys. Res. Commun. 173: 1043-1050.

39. Shroeder WA, Shelton JR, Shelton JB, Robberson B, Apell G. (1969) The amino acid sequence of bovine liver catalase: a preliminary report. Arch. Biochem. Biophys. 131: 653-655.

40. Murthy MR, Reid TJd, Sicignano A, Tanaka N, Rossmann MG. (1981) Structure of beef liver catalase. J. Molec. Biol. 152: 465-499.

41. Ivancich A, Jouve HM, Gaillard J. (1996) EPR evidence for a tyrosyl radical intermediate in bovine liver catalase. J. Am. Chem. Soc. 118: 12852-12853.

42. Ischiropoulos $\mathrm{H}$, Zhu L, Chen J, et al. (1992) Peroxynitrite-mediated tyrosine nitration catalyzed by superoxide dismutase. Arch. Biochem. Biophys. 298: 431-437.

43. Alvarez B, Rubbo H, Kirk M, et al. (1996) Peroxynitrite-dependent tryptophan nitration. Chem. Res. Toxicol. 9: 390-396.

44. Ischiropoulos H, Zhu L, Chen J, et al. (1992) Peroxynitrite-mediated tyrosine nitration catalyzed by superoxide dismutase. Arch. Biochem. Biophys. 298: 431-437.

45. Brown GC. (1995) Reversible binding and inhibition of catalase by nitric oxide. Eur. J. Biochem. 232: 188-191.

46. Kim YM, Bergonia HA, Muller C, et al. (1995) Loss and degradation of enzyme-bound heme induced by cellular nitric oxide synthesis. $J$. Biol. Chem. 270: 5710-5713.

47. Mohazzab-H KM, Fayngersh RP, Wolin MS. (1996) Nitric oxide inhibits pulmonary artery catalase and $\mathrm{H}_{2} \mathrm{O}_{2}$-associated relaxation. Am. J. Physiol. 40: H1900-H1906.

48. Asahi M, Fujii J, Suzuki K, et al. (1995) Inactivation of glutathione peroxidase by nitric oxide. Implication for cytotoxicity. J. Biol. Chem. 270: 21035-21039. 
49. Giuffre A, Sarti P, D'Itri E, et al. (1996) On the mechanism of inhibition of cytochrome c oxidase by nitric oxide. J. Biol. Chem. 271: 33404-33408.

50. Padmaja S, Squadrito GL, Pryor WA. (1998) Inactivation of glutathione peroxidase by peroxynitrite. Arch. Biochem. Biophys. 349: 1-6.

51. Roberts ES, Lin HL, Crowley JR, et al. (1998) Peroxynitrite-mediated nitration of tyrosine and inactivation of the catalytic activity of cytochrome P450 2B1. Chem. Res. Toxicol. 11: 1067-1074.
52. Yamakura F, Taka H, Fujimura T, Murayama K. (1998) Inactivation of human manganesesuperoxide dismutase by peroxynitrite is caused by exclusive nitration of tyrosine 34 to 3-nitrotyrosine. J. Biol. Chem. 273: 1408514089.

53. MacMillan-Crow LA, Crow JP, Thompson JA. (1998) Peroxynitrite-mediated inactivation of manganese superoxide dismutase involves nitration and oxidation of critical tyrosine residues. Biochem. 37: 1613-1622. 